\title{
Kulturális törésvonalak és regionális identitás Lengyelországban
}

\section{Terület és identitás}

A területi kötődés, regionális identitás nagy jelentőséggel bír Lengyelországban. A mintegy másfél évszázadon át tetszhalott állapotban lévő, a környező nagyhatalmak által 1795-ben véglegesen felosztott egykori állam lengyelsége - határok és intézmények által definiált állam hiányában - a közös történelmi hagyományokban, kultúrában, vallásban, egykori írásbeli és szellemi emlékekben volt kénytelen saját összetartozás-tudatát megélni. Az első világháborút lezáró békekötések teremtették meg az önálló Lengyelországot, melynek határait eredetileg a tervezőasztaloknál jelölték ki, s amelyet több évig tartó folyamatos háborúskodást követően a lengyel nép maga egészített ki történelmi küldetéstudatukat középpontba helyezve. A határok, melyek egyaránt elválasztanak és összekötnek, szorosan összefüggnek a régió, valamint a regionális identitás kérdésével. Jelen tanulmány - Lengyelországot középpontba helyezvén -ezt a kérdést próbálja több szempontból értelmezni. Nem feledkezhetünk meg ugyanakkor a határok, törésvonalak vizsgálata mellett a régió fogalmának értelmezésérôl sem.

A földrajztudomány s annak rokon tudománya, a regionális tudomány elválaszthatatlan a régió fogalmától, vizsgálatának tárgyát képezi, egyik alapvető vizsgálati iránya a ,régiót alkotó elvek megadása, mindezeknek a társadalmi és környezetitermészeti hatások általi elemzése". A régióvá válás folyamatának vizsgálatánál az időbeliséget is figyelembe véve az alábbiak szerint érzékeltethetjük a folyamatot. ${ }^{1}$

\section{HATÁR $\longrightarrow$ KOHÉZIÓ $\longrightarrow$ IDENTITÁS, IRÁNYÍTÁS}

Más vélemények alapján a nemzetközi politikai viszonyok elmélete négy olyan meghatározó elemet különít el, melyek hiányában nem beszélhetünk régióról.

1 A fenti kérdéssel foglalkozott egyebek mellett Szabó Pál (Szabó 2005), illetve Schmidt Andrea (Schmidt 2010) is. 


\section{1. táblázat. A régiók kialakulásának összetevói}

\begin{tabular}{|l|l|}
\hline $\begin{array}{l}\text { földrajzi elem } \\
\text { politikai elem }\end{array}$ & területi egység \\
\hline gözös érdekek, illetve problémák \\
\hline történelmi elem & $\begin{array}{l}\text { a nemzetgazdaság komplexitás kényszere és a gazdasági autarchia lehetetlensége } \\
\text { gazdasális és szociális homogenttség }\end{array}$ \\
\hline
\end{tabular}

Forrás: a szerző szerkesztése Éger György (Éger 2000) és Luiza Bialaszewicz (Bialaszewicz 1999) alapján

Létezik olyan megfogalmazás is, mely szerint a régiót nem a tér teszi, hanem az idő, a történelem. ${ }^{2}$ Ezek a megállapítások közel állnak az ún. regionális transzformáció folyamatához. Paasi (2002) és Bialasiewicz (1999) értelmezése szerint a regionális tudat, a regionális identitás keletkezése és léte számos tulajdonsággal jellemezhető, egyebek mellett a területi jelképek meglétével, de magával az elnevezéssel is. Ezek mindegyike egységteremtő képességgel rendelkező fogalom, melyhez az összetartozás képzete köthető. Magában hordozza az egymásra utaltság kérdését is, mely Közép-Európában szoros kapcsolatban áll a történelem kiemelt szerepével; az egyéni és a kollektív - ez utóbbit nevezi Bialasiewicz nemzetinek - történelmi tapasztalattal.

Paasi értelmezésében a régió közepes méretű területet jelöl, amelyet nem lehet közvetlenül megélni, de amelyet szimbolikus jelleggel beépíthetünk a tudatunkba. A régió különbözik a ,hely” földrajzi fogalmától, melyet a mai társadalomföldrajz képviselőinek nagyobb része rendszerint olyan területi egységnek tekint, amely az egyén mindennapi élete során egyre személyesebb jellegúvé válik. A régiók hosszú történelmi folyamat eredményeként jönnek létre, amelynek során a régió polgáraiban sajátos összetartozás tudat fejlődik ki.

\section{Szimbolikus terek}

A néprajz és a történeti geográfia mezsgyéjén mozgó szimbolikus földrajzzal foglalkozó iskola a térbeliség egy másik modelljét, a történelem, a történelmi narratívák „tájba írását”, valamint a konstruált táj és a konkrét földrajzi terekben tárgyiasuló szimbolika összhangját vizsgálja. Feltételezésük ${ }^{3}$ szerint a tájak a kulturális, mentális emlékezet részei, a nemzeti lét ikonográfiájának esszenciális részei, a nemzethez, régióhoz való kötődés kialakulhat spontán módon, de az állam erőszakos úton is kikényszerítheti a nemzethez tartozás egyenletes, folyamatos és homogén területét. Ah-

2 Történeti régiónak nevezzük azt a földrajzi-történeti egységet, melyet a történelem folyamán tartományként kezeltek, és/vagy területi-közigazgatási autonómiát élvezett, és a régió léte meghatározott időtartamra igazolható.

3 Magyarországon Ilyés Zoltán néprajz és geográfia határmezsgyéjén mozgó írásai, a nemzetközi szakirodalomban Maurice Halbwachs és Arjun Appadurai munkássága köthetôk ide. 
hoz, hogy egy tájat egy nemzet magáénak érezzen, nem okvetlenül kell annak földrajzi, politikai és történelmi határokhoz köthetőnek lennie. Lengyelországban, talán éppen a hosszan tartó ország nélküli nemzeti összetartás szükségessége, valamint a gyakran változó államhatárok miatt, kiemelt jelentősége van a kollektív történelmi emlékezetnek. Ezt példázza a Bialasiewicz által is kutatott Galícia-mítosz, vagy a lengyel történeti földrajzban szinte közhelynek számító Kresy (Végek) - az egykor Lengyelországhoz, 1945-öt követően Szovjetunióhoz, majd Ukrajnához tartozó területek esete. Míg az elóbbi a lengyel történelmi szimbolikában az önálló, független állam születésének bölcsője, ,lengyel Piemont”, addig Kresy az elvett, illetve megszerzett területek együttes halmaza. Míg Galíciát viszonylag könnyen be lehet határolni a történelmi térképeken a Habsburg Birodalom, majd az Osztrák-Magyar Monarchia egyik tartományaként, addig Kresy olyan terület, mely a történelem folyamán a kollektív emlékezetben manifesztálódott (Kolbuszewski 1996, Lorek é.n.). ${ }^{4}$

A régió nem állandó, statikus kategória, hanem dinamikus társadalmi jelenség. Mint ilyen állandóan változik, átalakul, folyamatként értelmezhető. A régiók születnek és eltúnnek, következésképpen a társadalom regionális felfogása is folyamatosan változik. Azt a folyamatot, melynek során egy bizonyos régió a társadalom térbeli szerveződésének részeként fejlődik, a régió intézményesülésének nevezik. A folyamat első szakaszában a régió szert tesz határaira, identifikálódik a társadalom területi szervezetében. A második szinten alakulnak ki a területi szimbólumok; ezek közül különösen fontos maga a régió neve, elnevezése (Vö. Paasi 1989 és Bialasiewicz 1999). A harmadik fokozat a régió saját intézményeinek, társadalmi szervezeteinek kialakulása, illetve ezeknek a társadalmi tudatba való rögzülése. A negyedik szakasz pedig a régió „hivatalos" intézményesülése, mely több mozzanatban is megfogható. A fenti négy szakaszt alapul véve a régió intézményesülési folyamatának legteljesebb formája a nemzetállam kialakulása is lehet. Ebben az esetben ugyanis jelen van a fenti fokozatok valamennyi fizikai és szellemi kelléke és terméke; terület, határ, név, nyelv, szimbólumok, intézmények. (Éger 2000). Természetesen nem minden régió lesz nemzetállammá, de az intézményesülési folyamat eredménye a nemzetállam kialakulása is lehet. ${ }^{5}$

\section{2. táblázat. A régiók intézményesülésének folyamata}

\begin{tabular}{|c|c|}
\hline 1. Területi keretek kialakulása & Határok kialakulása, identifikálódása a társadalom területi szervezetébe \\
\hline 2. Fogalmi keret létrejötte & Területi szimbólumok kialakulása, a régió elnevezésének kialakulása \\
\hline $\begin{array}{l}\text { 3. Intézmények, társadalmi } \\
\text { formák megteremtése }\end{array}$ & Intézmények társadalmi tudat részévé válnak \\
\hline $\begin{array}{l}\text { 4. Hivatalos intézményesülés, a } \\
\text { regionális öntudat kiteljesedése }\end{array}$ & Nemzetállamok kialakulása/ vagy autonómia elnyerése \\
\hline
\end{tabular}

Forrás: a szerzố szerkesztése

4 A történészeknél hasonló megállapításra jut Gerő András is, aki a megélt történelem és a „kitalált" történelem közötti kapcsolatot vizsgálta (Gerő 2004).

5 Ez a folyamat a közép-európai régió esetében meglehetősen megkésetten, csak a 19. század végére vált meghatározóvá.

6 Paasi (1989) és Éger (2000) alapján. 
A régiók mint történetileg is felfogható, összterületet felölelő szociális hálók megfelelően kiegészíthetőek más dimenziókkal is. A régió jelként, jelentőségként, képként és elképzelésként mutatkozhat, miközben a keletkezett képek a kollektív tapasztalatban a ritualizálódás következtében tovább hagyományozódnak, és a mindennapi életben megerősödnek. Képesek saját maguk identitást létrehozni, mélyreható migrációs tapasztalaton keresztül (Ipsen 1993).

A régiót mint a történelem folyamán kialakult átalakítható térséget a kulturális, nyelvi, helyi vagy természeti sajátosságok területi összesúrúsödése, illetve főként a lakosság azonos területre vonatkoztatott összetartozásérzete - ez az ún. regionális identitás - jellemzi. Ennek (újbóli) megtalálásának kérdése szorosan összefügg a határok jelentéstartalmának - mint az identitás kifejezésének egyik lehetőségének változásával. A határt fentrôl (államilag kialakított), kívülrool (háborús győztesek által) és belülról (nemzeti igények) egyaránt megteremthetik. A nemzeti identitás képes alkalmazkodni az új államhatárokhoz, ehhez azonban idôre van szükség, s a történelmi igények azután is megmaradnak, hogy a geopolitikai viszonyok régen újrarajzolták a nemzeti határokat (Bialasiewicz, 1999).

A regionális identitás olyan elméleti kategória, amely két síkon értelmezhető; egyfelől az objektív, materiális szféra, amely magába foglalja a természeti, kulturális, gazdasági elemeket, valamint a szubjektív elemek, amelybe beletartozik az egyéni, valamint a kollektív reprezentáció. A regionális identitás, a regionális reprezentáció elsősorban a régió lakosságának kifelé való képviselete, amely a régió és lakossága közötti viszonyt erősítheti, például az újságok, kommunikáció, politikai szerepvállalás terén - tulajdonképpen az én-tudat erôsítése.

A régió mint természeti és társadalmi jelenség is vizsgálható. Ipsen (1997) alapvetően az egyéni nézőpontjából vizsgálja a folyamatot. Az ő konceptualizálásában három előfeltétel szükséges ahhoz, hogy egy teret régióként értelmezhessünk;

1. a kontúrok - azaz a határok, a határ, amely elválasztja a régión belül és kívül található dolgokat, a belsôket összeköti, mint például a saját nyelv kultúra stb.

2. a komplexitás - az ún. speciális helyek, mint például a természeti környezet, tájak, történelmi helyszínek, sajátos építészet, a saját terek, ahol a társadalmi élet színterei találhatóak stb.

3. a koherencia - azok a közösségi erőt képező tényezők, amelyek a régiót mint entitást jellemzik, s melyek a regionális kohéziót és szolidaritást képezik.

A kontúrok, a komplexitás, valamint a régió koherenciája együttesen alkotja az egyén régiófelfogásának alapjait. Ez a térfelfogás a különböző régióképző elemek interakciójaként értelmezhető. Egyszerre foglalja magába térfelfogást, a jelképeket, a tér területi manifesztálódását, illetve a térfejlődés elemeit. Az egyénben tehát kialakul egyfajta sajátos térfelfogás, a közösségi percepció pedig a régiót valódi vagy jelképes határokkal látja el. 


\section{Közép-európai törésvonalak}

Timothy Garton Ash A közép-európai rejtvény címú írásában egy 1954-ben megjelent tanulmányt idéz, amelynek szerzője, Karl A. Sinnhuber 16 Közép-Európa-definíciót hasonlított össze. Az Ibériai-félsziget volt az egyetlen olyan része Európának, amelyet egyik meghatározás sem foglalt magában, Ausztria, Csehország és Morvaország pedig az egyetlen olyan térség, amely mindegyikben szerepelt. Ha lengyel szemszögből nézzük a problémát, hol húzódnak a tulajdonképpeni határok, számos értelmezés született a 19. századtól kezdődően. Grzegorz Gorzelak (Gorzelak-Jałowiecki 2002) értelmezése mintegy kiegészíti Huntington elméletét. Gorzelak Lengyelországot a nyugati terület peremvidékéhez sorolja a mai balti államokkal, valamint Csehországgal, Szlovákiával és Horvátországgal egyetemben. Kulturális hasadéknak az építészeti stílusok közötti különbséget tekinti, választóvonalnak a Visztula folyót, a törésvonalat pedig ,,aranyfüggönynek” nevezi. ${ }^{7}$ Lengyelország Kelet és Nyugat között képez átmenetet.

A közel másfél évszázadot felölelő megosztottságból, az önálló állam hiányából adódóan az összetartó erôt a vallás, valamint a lengyel nemzethez tartozás tudta biztosítani. A katolikus vallás és a latin nyelvú kultúrához való tartozás határokon túlmenő kohéziós erôként tudott funkcionálni. A nemesi köztársaság idején elterjedt szólás is a latin múveltséget volt hivatott kifejezni. Polonus sum nobilis Latine loquor - lengyel nemes vagyok, latinul beszélek. Ez volt a viszonyítási pont a három felosztó birodalom lakossága körében. Az ország legnagyobb területi kiterjedését az 1569 és 1572 közötti időszakban érte el, ezt a korszakot a lengyel történettudomány aranykornak nevezi. Ez volt a lengyel-litván nemesi köztársaság (commonwelth) időszaka, amit a lengyelség ,tágabb hazának” nevez.

\section{A felosztott Lengyelország - kulturális törésvonalak}

A lengyelség eltérő módon élte meg saját sorsának alakulását a három birodalomban. Míg Poroszországban, majd az egységesülő Németországban az 1870-es évek germanizáló hatása ellen nem sok esélyük volt az ott élő lengyeleknek szavukat hallatniuk, a Habsburg Birodalomban az osztrák és magyar kormányok fokozatos demokratizálásra törekedtek. ${ }^{8}$ A 19 . század végére Galícia egyre nagyobb autonómi-

7 Az aranyfüggöny elhelyezkedése egybeesik a valamikori vasfüggöny vonalával, s ha - mintegy húsz évvel a rendszerváltást s közel tíz évvel az Európai Unióhoz való csatlakozást követóen - megnézzük az EUROSTAT egyes statisztikai régiók gazdasági fejlettségre vonatkozó adatait, azt láthatjuk, hogy a politikai megosztottságtól függetlenül a gazdasági megosztottság (nevezhetjük jóindulatúan törésvonalnak, de akár szakadéknak is) továbbra is fennmaradt.

8 „A Habsburg Birodalom nem volt földi paradicsom, de ha viszonylag objektíven tekintünk a három elrabolt országrészre, rögtön szembetúnik a különbség az oroszok tekintélyelvú, lengyelellenes uralma, a sajátos porosz jogrend és az osztrák - magyar kormányok fokozatos demokratizálása között." (Brakoniecki 2003) 
ára tett szert, ami múködő parlamentet, felsőoktatást, virágzó lengyel irodalmi-kulturális életet jelentett - Lwów (Lemberg) központtal. ${ }^{9}$ Ez a viszonylagos önállóság a nemzeti kisebbségek számára is előnyös volt, itt teremtették meg a lengyel állam alapjait, nem véletlenül nevezték Galíciát ,lengyel Piemontnak” (Bialasiewicz 1999). A három terület közül legmaradandóbb élményt az orosz fennhatóság jelentette. Az Oroszország által okozott sebek és szenvedések ezerféleképpen íródtak be a lengyelek emlékezetébe, s élnek a mai napig különféle szólások, metaforák, célzások, ikonikus jelek, idézetek, magatartásminták formájában. A lengyel nyelvben és kultúrában ott kísért az elnyomó, zsarnoki Oroszország képe. Ez a vízió a lengyel kultúra tudása, bölcsessége, melyet megszámlálhatatlan, szüntelenül jelen lévő és ismétlődő bizonyíték támaszt alá. E mélységes bizonyosság tudata a lengyel identitás egyik alappillére (Grudzinska-Gross 1997). A lengyel értelmiségiek úgy fogták fel az Oroszország elleni harcot, mint az európai civilizáció védelmét egy despotikus és barbár birodalommal szemben, és Európához fordultak segítségért.

\section{1. ábra: Lengyelország határainak változása az államalapítástól 1945-ig}

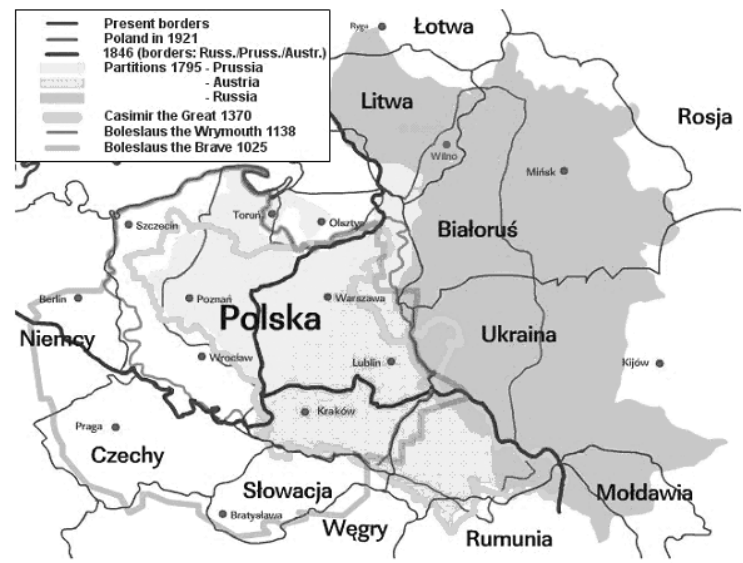

Forrás: www.staypoland.com/history-fr.htm

9 „Megkockáztathatom azt a kijelentést, hogy a viszonylag liberális Ausztriának köszönhetjük a függetlenséget, legalább is az osztrák fennhatóság alá került országrészben alakították ki a lengyelség új formáját, ott teremtették meg a hadsereg és a közigazgatás személyi hátterét (...) nekünk is megvoltak a magunk problémái (...) Galíciában elviselhetetlen volt a parasztok nyomora, leverték a felkelő nemességet, a függetlenségre semmi remény és valahogy élni is kellett.” (Brakoniecki 2003) 


\section{Lengyelország belsố törésvonalai}

Az 1939-ben kettéosztott Lengyelország a világháborút követően új határok között helyezkedett el. A szocializmus egyik fő törekvése az egyenlőtlenségek leküzdése volt, a történelmileg kialakult különbségek feloldása nem volt problémamentes. A szocializmus idején kialakult fejlettségbeli különbség megosztotta Lengyelországot észak-dél irányban az ország keleti határvidéke mentén. A geopolitikai változások eredményeként az 1945 után, de különösen a rendszerváltást követően perifériára került egykori területek a valamikori Lengyelország központi területeit alkották az egykor keleti irányban húzódó ország félperifériájaként a mezőgazdasági ágazat túlsúlyával. A 20. század harmincas éveitől kezdve alakították ki itt a Központi Iparvidéket, s telepítettek ide számos stratégiai jelentőségú ipari üzemet, melyek a háború végével vagy megsemmisültek, vagy pedig a határváltozás következtében elvesztették a hátországukat. A szovjet minta hú másolása, a nehéziparnak, ezen belül a bányászatnak előtérbe helyezése ugyancsak nem tett jót e régió fejlődésének. A szocialista Lengyelország az egész keleti övezettel mostohán bánt, az egész országot érintő fejlesztési programokból kihagyták a területet. A keleti határ közelsége, viszonylagos zártsága nem tette lehetôvé a további fejlődés lehetőségét, a szomszédos országokkal folytatott kereskedelem sem kapott újabb impulzusokat. A terület gazdasági mutatóinak, adottságainak, lehetőségeinek számbavételét követően nem véletlenül kapta a „Polska B” elnevezést megkülönböztetendő a fejlettebb és urbanizáltabb „Polska A”-tól.10

Lengyelországon belül létezik egy úgy nevezett belsố perifériális törésvonal az egykori felosztott területek határvidékein, melynek megléte ugyancsak történelmi okokra vezethető vissza. A porosz-osztrák, orosz-osztrák egykori határok, melyek 1918 óta már nem létező belső választóvonalak, továbbra is ôrzik a határjellegüket, még ha azok manapság már az ország belsejében, a tényleges országhatároktól távol találhatók. Ez nyomon követhető a képzeletbeli két oldalon elhelyezkedő területek több generáció óta ott élő családjainak körében, merőben más politikai kultúrával rendelkeznek, eltérô a választásokon való részvételi hajlandóságuk, kicsi az átjárás az egymástól akár csak néhány kilométerre fekvő települések között, nem házasodnak egymás között. ${ }^{11}$ A megosztottság mint adottság a választási térképeken is markánsan megmutatkozik. A 2005-ös, 2007-es és 2011-es parlamenti választások esetében a választópolgárok pártpreferenciáit vizsgálva éppúgy szembeötlő ez a megosztottság, mint ahogy a 2010-es köztársasági elnöki választásoknál is ugyanez a tendencia figyelhető meg.

10 Ezzel részletesebben foglalkozik Czerny (é. n.).

11 Érdekes vizsgálat zajlott a krakkói külső agglomerációban 2003 körül. Itt húzódott az egykori oroszosztrák határ. A vizsgálat során azt tapasztalták, hogy az újraegyesítés óta eltelt mintegy hét és fél évtized és a nagyvárosból kiköltöző́k eredményeként bekövetkező lakosság összetételbeli változás ellenére is kicsi az átjárás, átházasodási hajlandóság a két terület között, noha a települések között alig néhány km a távolság. 
2. ábra: Parlamenti választások és az egykor felosztott Lengyelország határai, 2005

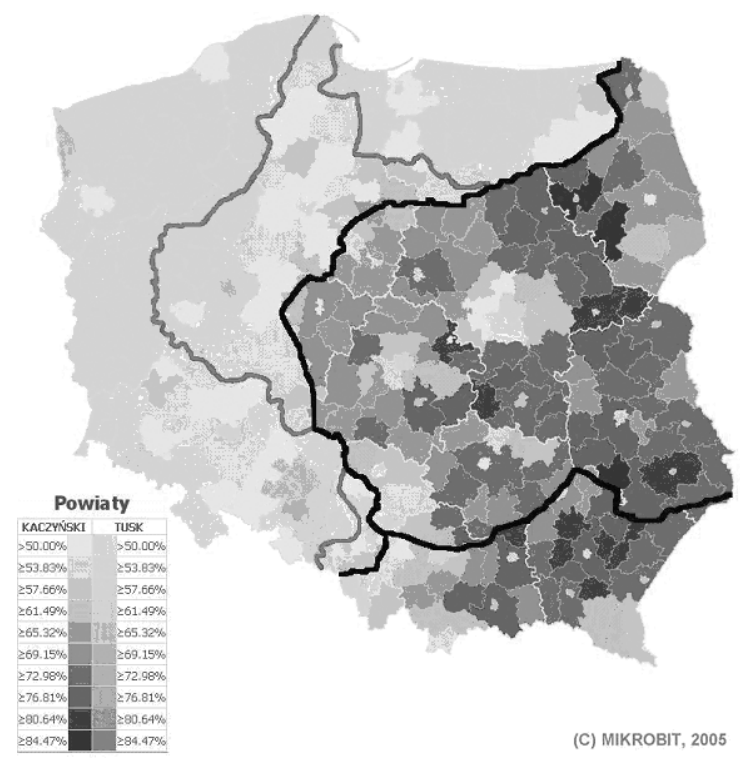

Forrás: http://bezwodkinierazbieriosz.salon24.pl/195521,wybory-w-polsce-wybory-w-rosji

3. ábra: Parlamenti választások, 2007

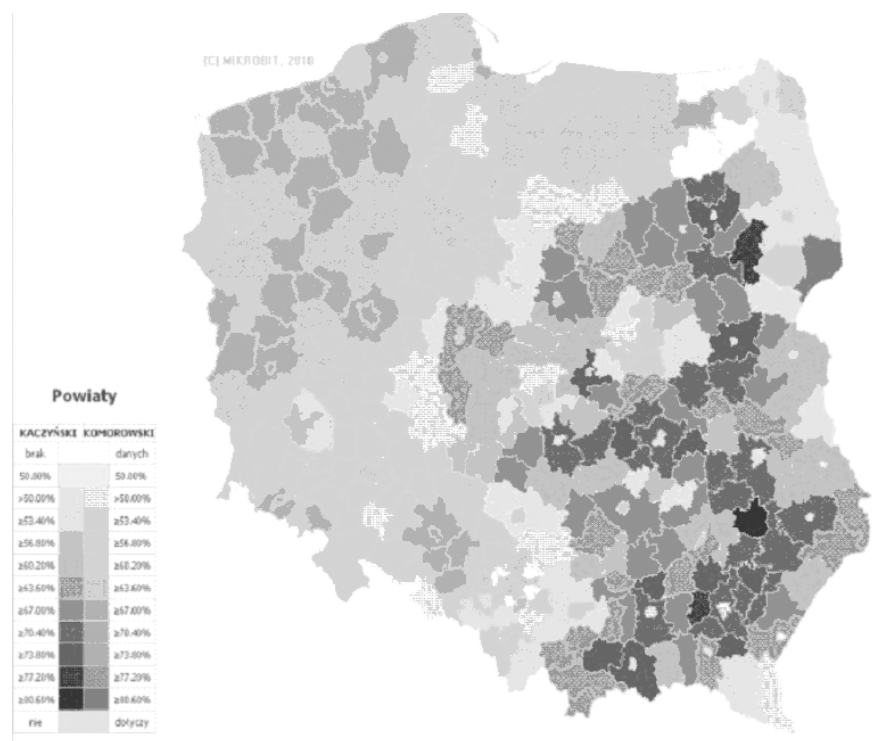

Forrás: http://pl.wikipedia.org/wiki/Wybory_parlamentarne_w_Polsce_w_2007_roku 


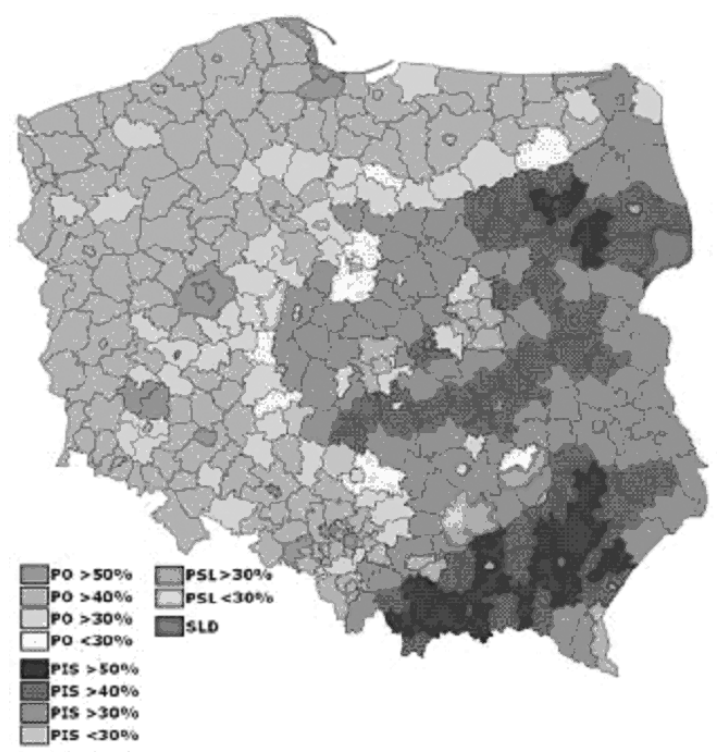

Forrás: http://www.fronda.pl/blogowisko/wpis/nazwa/wyniki_wyborow_inaczej_30850

\section{Lengyelország és az Európai Unió}

Az 2004-ben, illetve három évvel később csatlakozott uniós tagállamok is új kihívással voltak kénytelenek szembesülni, hiszen versenyhelyzetbe kerültek a korábbi tagállamokkal. A területi széttagoltság kevésbé markánsan jelentkezett. Az Unió kibővítése tehát érzékelhetően növelte a fejlettségbeli különbségeket, amely Lengyelország esetében az alábbi következményekkel járt együtt (Gorzelak 2007):

Lengyelországban több kísérlet zajlott a belsô törésvonalak mérséklésére, többkevesebb sikerrel. A fejlesztésprogramok rendre a területi kiegyenlítődésre koncentráltak, vagy legalább is, célként ezt fogalmazták meg. Ugyanakkor a statisztikai mutatók és a lakosság választópolgári magatartása ellenkezố tendenciáról tanúskodnak. A történelmileg kialakult törésvonalak mellé a piacgazdaság újabbakat hozott létre. Kialakult egy települési törésvonal is a már történelmileg adott Polska A és B mellett megjelent a „Polska C” kategória is, azaz a korábban fejlettnek vélt területen belül is formálódóban van egy nagyváros s környezete közötti törésvonal, vagyis az eddigi kétosztatú rendszer háromosztatúvá vált. Az Európai Unióhoz való csatlakozás eredményeként ugyan az egész Kelet-Lengyelországot felzárkóztató Operatív Program került meghirdetésre, de a remélt eredmények egyelöre váratnak magukra. 


\section{Hivatkozott irodalom}

Ash, Timothy Garton (1990): The Magic Lantern: The Revolution of 1989 Witnessed in Warsaw, Budapest, Berlin, and Prague. New York, Random House.

Bialasiewicz, Luiza (1999): Reordering Europe's Eastern Frontier: Galician Identities and Political Cartographies on the Polish-Ukrainian Border. Kézirat, 1-6.

Borowska, Iwona (2008): Polska Polsce nierówna [Lengyelország nem egyenlö].Internet:http://wiadomosci.polska.pl/specdlapolski/article,,id,331312.htm

BRAKONIECKI, KAZIMIERZ (2003): Világtan. Magyar Lettre Internationale (51). Internet: www.c3.hu/scripta/lettre/web/index.htm, 1-3.

CZERny, MirosŁaw (szerk.) (2006): Poland int he Geographical Centre of Europe. New York, Nova Science.

ÉGER GYÖRGY (2000): Regionalizmus, határok és kisebbségek Kelet-Közép-Európában. Budapest, Osiris, 24-50.

GERő ANDRÁs (2004): Képzelt történelem. Fejezetek a magyar szimbolikus politika XIX-XX. századi történetéból. Budapest, ELTE-PolgArt, 12-20.

GorzelaK, GrzegorZ-JaŁowiecki, Bohdan (2002): Unity or Division of the Continent? Regional Studies 36 (4), 409-419.

GORZELAK, GRZEGORZ (2007): Rozwój, region, polityka [Fejlődés, régió, politika]. In Rozwój, region, przestrzeñ. Varsó, Warszawa, Ministerstwo Rozwoju Regionalnego, Centrum Europejskich Studiów Regionalnych i Lokalnych, Uniwer-sytet Warszawski, 179-215.

IPSEN, DETLEV (1997): Raumbilder. Kultur und Ökonomie räumlicher Entwicklung. Pfaffenweiler, Centaurus, 36-40.

IPSEN, Detlev (1993): Regionale Identität. Überlegungen zum politischen Charakter einer psychosozialen Raumkategorie. Raumforschung und Raumordnung 51 (1), 9-18.

KolbuszewsKi, JACEK (1996): Kresy. Wrocław, Wydawnictwo Dolnośląskie, 7-28.

LOREK, ANDreas: Poland's role in the development of an 'Eastern dimension' of the European Union. Szakdolgozat. Internet: http://books.google.hu/ books?id=lsmgmbbKD9MC.

PAAsi, ANSSI (1989): A régiók fejlődése és a regionális identitás kialakulása. Tér és Társadalom 3 (3), 70-79.

PAASI, ANSSI (2002): Place and Region: Regional Worlds and Words. Progress in Human Geography 28 (6), 802-811.

RÁK VIKTOR (2002): Regionalizmus az Európai Unióban. In Szentes D. (szerk.): Új generáció a közigazgatásban. Budapest, Tempus Közalapítvány, 7-22.

SCHMIDT ANDREA (2010): Törésvonalak és területfejlesztés Lengyelországban - adottságok, szereplók, intézmények, perspektívák. Doktori disszertáció, kézirat. Pécs, PTE.

SzABó PÁl (2005): Régió: Meghatározott területi egység. In Régiók távolról és közelról. Budapest, ELTE Regionális Földrajzi Tanszék, 7-63.

www.staypoland.com/history-fr.htm, letöltés ideje: 2012. 03. 18. 
http://www.fronda.pl/blogowisko/wpis/nazwa/wyniki_wyborow_inaczej_30850, letöltés ideje: 2012. 05. 04.

http://pl.wikipedia.org/wiki/Wybory_parlamentarne_w_Polsce_w_2007_roku, letöltés ideje: 2010. 10. 16.

http://bezwodkinierazbieriosz.salon24.pl/195521,wybory-w-polsce-wybory-wrosji, letöltés ideje: 2012. 03. 22. 